UCRL-JC-121582

PREPRINT

\title{
X-ray Spectroscopy and Imaging of a Plasma Collision
}

C. Chenais-Popovics, O. Rancu, P. Renaudin, J. C. Gauthier, F. Gilleron, O. Lindenmeyer, H. Kawagoshi, M. Dirksmoller,

I. Uschmann, T. Missala, P. Sondhauss, E. Förster, O. Renner,

E. Krousky, H. Pépin, O. Larroche, O. Peyrusse, T. D. Shepard

This paper was prepared for submittal to the SPIE Conference

San Diego, CA

July 12-14, 1995

July 14, 1995

This is a preprint of a paper intended for publication in a journal or proceedings. Since changes may be made before publication, this preprint is made available with the understanding that it will not be cited or reproduced without the permission of the author. 
DISCLAIMER

This document was prepared as an account of work sponsored by an agency of the United States Government. Neither the United States Government nor the University of California nor any of their employees, makes any warmanty, express or implied, or assumes any legal liability or responsibility for the sccurncy, completeness, of esefulness of any information. apparatus, product, or process disclosed. or represents that its use would not infringe privately owned rights. Reference berein to any specific commercial products, processe, or service by trade name, trademark, manufacturer, or otherwise, does not necesasurily constitute or imply its endorsewent, recommendation, or favoring by the United States Government or the University of California. The views and opinions of authors expressed herein do not necessarily state or reflect those of the United States Government or the University of California, and shall not be used for advertising or product endorsement purposes. 


\section{DISCLAIMER}

Portions of this document may be illegible in electronic image products. Images are produced from the best available original document. 


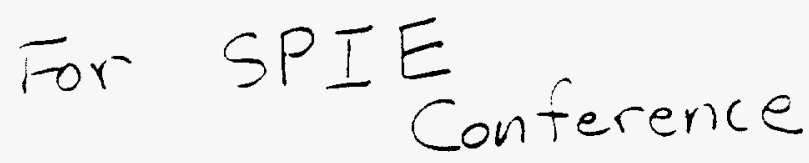

$X$-ray spectrascopy and imaging of a plasma colltsion

C. Chenais-Popurie:s. O. Rancu, P. Renaudin. J.C. Gatihier. F. Gilleron. O. Lindenmeyer. H. Kawagoshi*.

Luboratoure pour l'Utilisaluun des Lasers Intenses. Ecole Polytechnsque, 91120 Palaiseatr. France

M. Uirksmoller, I. Uschmann. T. Missudla. P. Sondhaues, E. Förster

Max-Plaulih Asbeitsgruppe Rontgenoptik, Friedrich-Schiller Universulut, Max-Wien Plazz I. Ix)//43 Jena. Germany

O. Renner, E. Krousky. Instutuie of Physics

Academy of Sciences of the Crech Republic. Prague, Czech Republic

H. Pepin.

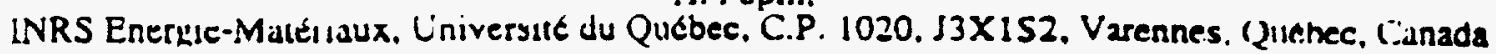

O. Lintuclic, O. Peyrusse

Centre d'Etudey de Limeil Vulenton, 94195 Villeneuve.Saint- ienrges Cedex. Prance

T.D. Shepard,

Lawrence Livermore National Laboratory, 1 :A -9455 I-0808. USA

- on leave from PNC:. Tokai. Japan

\section{ABSIRALT}

The collision of lascr-produced plasmas has been diagnosen hy $X$-ray spectroscopy and imaging. The two colliding plasmas are produced on Al thin foils at a distance of 200 in $900 \mu \mathrm{m}$ irradiated ut $\lambda=0.53 \mu \mathrm{nn}$ with lascr intensitics of $3 \times 111^{13}$ in $0 \times 10^{13} \mathrm{~W} / \mathrm{cm}^{2}$. Interpentelsation of the plasmas was visualisent hy replacing one of the foils malcrisl by magnesium. The main diagnostice viewing the inir.r-tirget space were ume-resolved ulunucliomatic imaging of the $1 \mathrm{~s}^{2} 1 \mathrm{~s} 3 \mathrm{p}$ aluminum line (He $\beta$ at $\lambda-6.635 \AA$ ), Doppler hrnadening ineasurement wilt d vertical Johann very high resolution spertingrapn in the range $0.5-6.7 \hat{A}$. space-tesoived higb resolution spectra of the dielectronic saleilites of the $15-2 p$ I.yman $n$ line $(7.1-7.2$ A). space-rosulved spectra with a flat-crystal spectrograph in the range $5-7 A$ and in the ranke of $43-48 \lambda$ obtained with a new OHM crystal spectruxsauli and a pinhole camcra. 1 multifluid eulerian monodimeneinnal hydrodynamic code coupled with a radianive-alomic parikage provided simulations of the experiments. Ilydrodynamic 2D simulations calculating the latcral expansion of the plarmn enabled a reliable treatment of reahomption along the line of sight of the spectrographs. The size and the lime duration of the collisiun, Uie plasma parameters (Te. Ti and ne) in the collision region and iniei pelletration were measured. The hydrocode simulations give a koud understanding of the behavior of the collision in tinnctinn of intertarget distance and loser intensity.

\section{LINTRODUCIUUN}

The collision of laser-prodiucen plusmas has not been muds studied experimentaily, but a number of numerical simulatiuns und theoretical papers have been published. Two main experimental schemes have heen explored: the collision of blownil plasmas produced at the fivul of thick laserirradiated targets ${ }^{1.7}$ and the collision ot the piasmas produced at rear sides of two laser-exploded thin 
foils8. The $X$-ray imaging and spectroscopic diagnostics have pruved tu be very powerful tools for the derminatiun uf luser-produced plasma perametcrs. We presont bere the study of the collision of plusmac produced on the rear of laser-irradiated inin inils. diagnosed by a number of differeul spectroscopic and imaging $\lambda$-rav covis. The expei issent has been also simulated with hydmdyamic and atomuc physic codes. The mass insight on the expenment has been obtainen hy cnmparing the experimental results with a II) enlierian multi-fluid code. In the present paper, we einphasize the spectroscopic methods which tiure led to the measurement of electron density and tempernture, jon temperanure and plasme dimensions and interpenetration in the collision regron.

\section{EXPCRIMLNTALSET.UP}

The expenment has been petformed with two frequency-duubled beams of the Nd glass laser of the Laburatvise puur l'Utilisation des Lascrs Intenses ( $L U L I$ ) facility at $0.53 \mu \mathrm{m}$ wavejength and with a pulso duration of 600 ps. The encrgy was inrilsen perpendicularly to the targets throuxli $f=250 \mathrm{~mm}$ lenses and random phasc plates to ubtall livillugeneous $200 \mu \mathrm{m}$ diameter FWHM focal spots. Laser intensity has been varied between $3 \mathrm{daJ} G \times 10^{13} \mathrm{~W} / \mathrm{cm}^{2}$. The targees were oither two aluminum thin foils $(0.8 \mu \mathrm{m}$ thick) or in aluminum foil in front of a magnesuim inil (1.0 $\mathrm{mm}$ thick). Inter-target diseance has been vartert from 450 to $900 \mu \mathrm{m}$ (sce Figure (d). The masu diagnostucs were probing $X$. ray emission pervendiculariy to the laser axis. They have been set-up on several experimental campaigns, using sometimes the same viewing axis

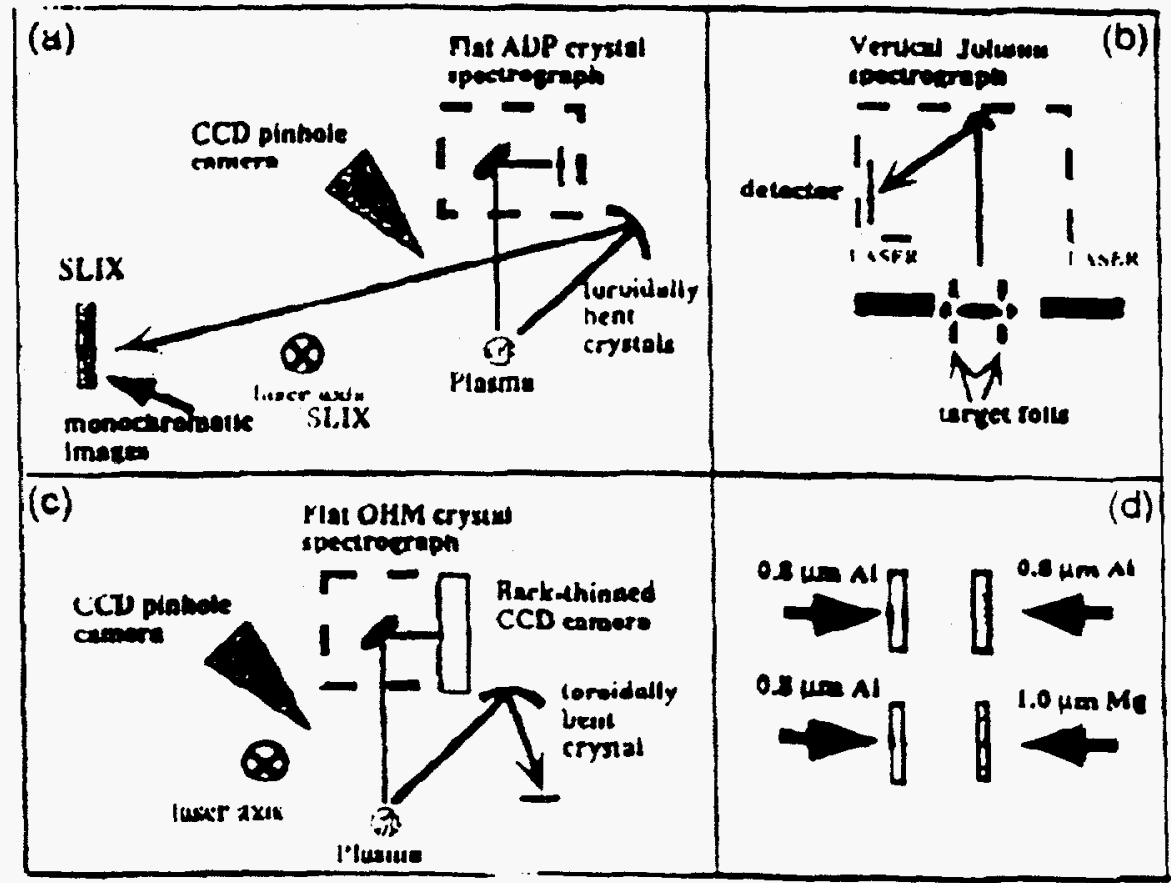

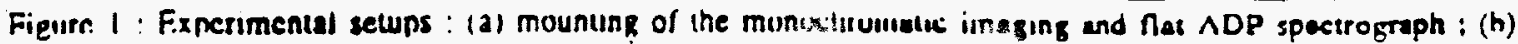

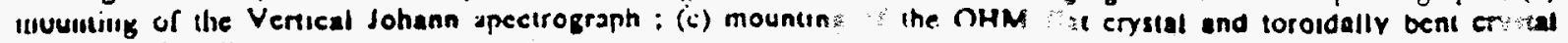
speetmeraph : (d) target mounane. 


\begin{tabular}{|c|c|c|}
\hline $05-67-1995$ & nsomtolfe ult & 3 : 697 mereg \\
\hline
\end{tabular}

Figure 1 shows the experimental set-ups including ine nifierent spectrographs and Imaging systems :

- iwol inrninally hent quartz crystal were imaging the $1 s^{2}-1830$ (HeB. $\lambda=6.035 \dot{A}$ ) eluission of aluminum with a space resulutiuti ur $35 \mu$ un otso two cathodes of a 120 ps resolution framing camera open al two differem lintes (Figure la); ${ }^{\circ}$

two time integrating spectrographx were viewing the intertarget space at $w)^{\mu} \mathrm{pmm}$ each nther:

(1) a classical flat ADP crystal with a slit of $35 \mu \mathrm{m}$ recording the $3.5 .7 \mathrm{~A}$ iekiun. i.e. the He-like and H-like lines of aluminum and Il-like lines of magnesium (Figure la).

(ii) a high rekolution verical Johann specerograph was set with a quarz $(10.0)$ crystal bent to 76.8 $\mathrm{mm}$ radius of curvature to record the widih of the aluminum Hep line. 10 The spectral resolvine power was limited in 2000-3000 due to the size of the plasma ( $2(\mathrm{~K})-\mathrm{Am} \mu \mathrm{m})$. This high resolution was necessary to measure the ion temperature frotn the Dupvler broadeaing of this line. The high luminosity of this instrument has made it very efficient to messure the interpenetration distanre. defined as llie distauce on which the aluminum IIe $\beta$ or the magnesium Lyman $\delta$ lines were visible over the threshold of the dotector:

- a very high resniution specirograph using a coroldally bent quari $(10.0)$ ciyslal was set on the dielectronic satellitesof the Lyman $\alpha$ H-like line in the $1.1-7.4 \mathrm{~A}$ range (Figure $1 \mathrm{c}$ ). The radil of curvanure were $146 \mathrm{~mm}$ in dispersion plane und $149 \mathrm{inm}$ in the perpeadiculur plaule. In the dispersion plank, llie specuugraph was in a Johann type geomery. with the film on the Rowland circle and the plasma inside this circle. In the plane perpendicular to the dispersion plane. the radius of curvature determined the distance to the source to ensure imaging willi 0.42 ulagnification and $10 \mu \mathrm{m}$ spatial iesolution onto the Rowland ciscle :

- the flut crysital spectrograph has been used with an ( tetadecyl-Hydrogen-Maleate (OHM) crystal with large inter-reticular distance $(2 A=63.5 A)$ (Figure $1 c)$. " The spectral range cuvered was 43 to $48 \mathrm{~A}$. The spectrugraplt lias been set with its $38 \mathrm{\mu m}$ wide slit parallel and perpendicular to the intertargot axis in order to meucure and compare the longitudinal non lateral spread of Be-like and He-llke inns. For the measurement of the latesal spread. the emissiun frum the foils was hidden and only the eitsission of the collision plasma wax reaching the spectrograph. A $512 * 512$ back-thinned C(:I) camera filcered with $0.3 \mu \mathrm{m}$ thick carbon foil was used as a detector.

- Finally. a pinhole camera flitered with ilutuiwized mylar was imaging the inter-target space.

\section{EXPERIMENTAL RESULTS}

\subsection{Ternpetulute uneasurements}

The data obtained on the vertical Johann alld flat ADP erystal spcctrograpts have been simultancously analyzed to deduce non-ambiguously the electron and ion temperatures. In rigine 2 is shown such the adjustment of the messumen spectra in the case of an interarget distance di of $560 \mu \mathrm{m}$ and a lacer intensity $I_{L}$ of $6 \times 10^{13} \mathrm{~W} / \mathrm{cm}^{2}$. The spectra are simulated with the collisional-radialive code FLY, the time-dependent versinn at KAlliON. 12 With a time variation deduced fiull the timeresolved inonochromatic images. This measurement has shnwn that the HeB line is emitted only during 150 us FWHM. The high resolution spectsal protile of the Heß line messured with the verical Johann spectrograph has boen fitted varying the ion temperature and the size of the plasma (Flgure 2a). The He-like and $\mathrm{H}$-like spectrum measured on the fal crystal spectrograph (Pigurc 2b) has been litled usiug the same plasma size, and varying the election temperature and density. The plasma size broadens the lines of both spectra ihrnigh reansorption. Addittonally. It bruadetis the nat crystal spectrum through Instrumental bivadening. Only an ordes of magnitude of electron density was obeained from these spectra which are not very dependent on this parameter. 

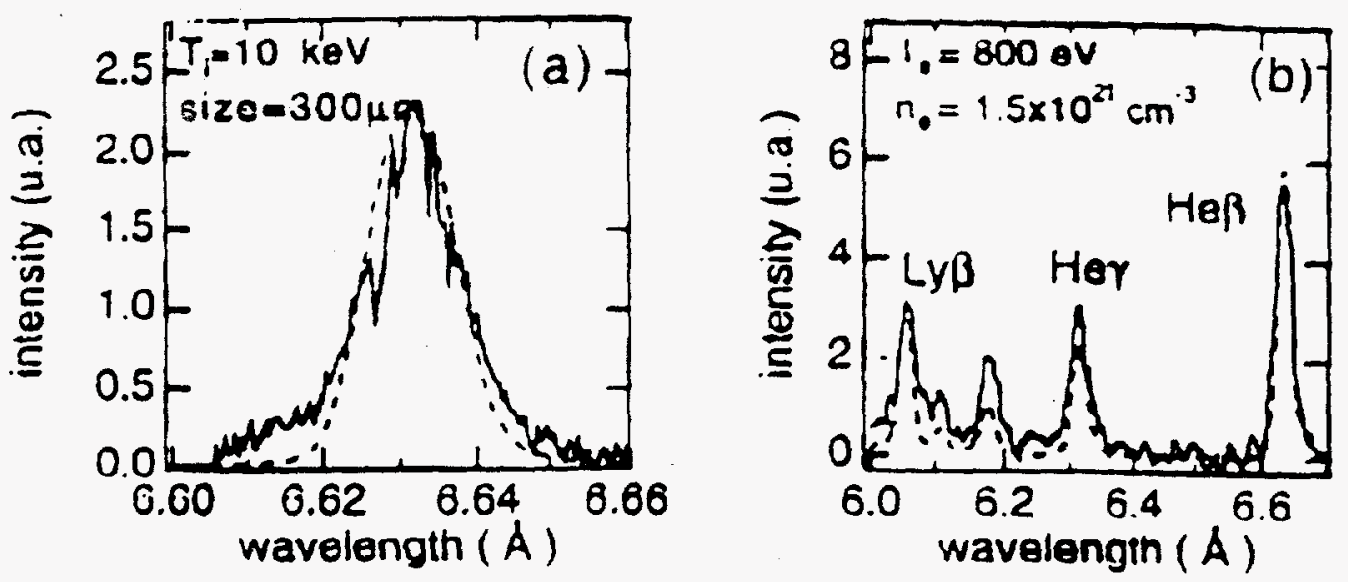

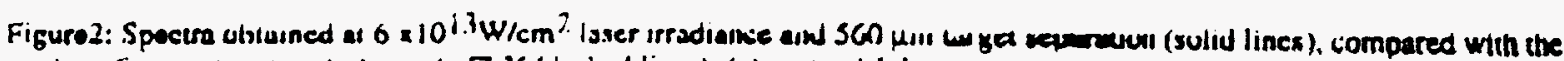

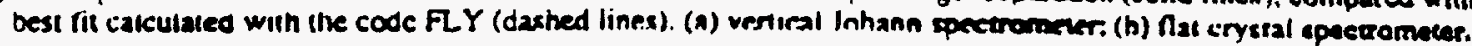

Radial gradienis, and I onpples shift due to lateral velocity have been neglected. This assumption was not trivial alld a Duvpler shift in a non-homogeneous ptasma could have changed the determination of $\mathrm{Ti}$. Thie assumptions of homogencily and smell lateral velocities have been justified by Lasnex 2D lagrangian simulialinns The results of these simulations ean be used here as maxima values as this single fluid lagranxian culc uverestimales the lateral expanston and velocity.

In LASNEX simulations. the lateral velocity in the high electron temperature region is asound 2 $x \quad 106 \mathrm{~cm} / \mathrm{s}$. inducing Doppler shifts on the order of $0.5 \mathrm{~mA}$. i.e. much smaller than the $10 \mathrm{~m} \lambda$ Dopplei widlt expeciced for in ion remperature in the range of $10 \mathrm{keV}$. Shon lateral gradients have also been mencured with the OHM crystal spectrograph as shown hereunder.

The parameters measured at the celles ul lle uncr-turcet space are grouped in table 1. They show that electron teinperatures stay in the range of 0.35 10 $1 \mathrm{keV}$. At high laser intensity, when interpenetration occurs. the mcasured inn temperamure nses in + in (1) keV

\begin{tabular}{|c|c|c|c|c|c|c|}
\hline \multirow[b]{2}{*}{$I_{1}\left(w / \mathrm{cm}^{2}\right)$} & \multirow[b]{2}{*}{$d_{i}(\mu \underline{m})$} & \multicolumn{2}{|c|}{ Fxn:nment } & \multicolumn{3}{|c|}{ MULTIF simulation } \\
\hline & & $T_{e}(k e V)$ & $T_{1}(\mathrm{keV})$ & Icumax & $T_{\text {manx }}$ & $T_{i 12}$ \\
\hline $3 \times 1013$ & 45() & $035 \pm 0.1$ & $0.35 \pm 0.2$ & 0.35 & 0.40 & \\
\hline $3 \times 10^{13}$ & 000 & $0.75 \pm 0.2$ & $1.00 \pm 0.3$ & 0.50 & 0 & $<2.5$ \\
\hline $3 \times 10^{13}$ & 900 & $0.8 \pm 0.3$ & $0.8 \pm 0.3$ & 0.55 & 4 & $<1.3$ \\
\hline $6 \times 10^{13}$ & 450 & $0.8 \pm 0.2$ & $10 \pm 3$ & 0.28 & 27 & 5.9 \\
\hline $6 \times 10^{13}$ & 600 & $0.8 \pm 0.2$ & $10 \pm 3$ & 1 & 20 & 7.1 \\
\hline$i \times 1013$ & $m(x)$ & $0 \div 4.3$ & $3 \pm 1$ & $0 \times 5$ & 18.5 & 5.3 \\
\hline
\end{tabular}

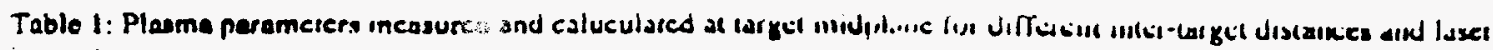
intensities. 


\subsection{Electron densuty measurements}

Clectron deisily lias been measured inure accurately fram the analyss of the He-like dielectronic salcllites of the Lyman $\alpha$ H-like line. I he pnnciple of the satellites measurements is a comparison of the measured ratios of diffetellt satellites with time-dependent collisional-radiative calcularions done with FLY with the time variation decribed above for temperature messuremenes. The electron lemperature range has been restncted to $600 \mathrm{~h} 1000 \mathrm{eV}$ using the provious measurements. From the four measured line ratios, regijus iu Usc (ne,Te) were determined. The cnmmnn telimited regions ghve a range of densities and temperalures. The ratios depend mosty on density, and tie widith on ton ieulperature. The diagnostic is not very de.pendent on elcctron temperature. Non stationnary effects are impurtant mosdy at densities lower than.$\times 111^{21} \mathrm{~cm}^{-3}$ The uncertainty of the electron temperature gave an uncertainty on the determination uf lice density. The expertmental spectrum can also be directly comparest to the simuluted one as shown in Figure 3 . The data are still under analysis. One shot has been completely analyzen giving a eleetron clensity of $(1.5 \pm 0.5) \times 10^{21} \mathrm{~cm}^{-3}$ und a ion celupeiatuic of $3.4 \mathrm{keV}$ for a laser intensity of $5 \times 111^{13} \mathrm{~W} / \mathrm{rin}^{2}$ and an inter-larget distance of $450 \mu \mathrm{m}$.

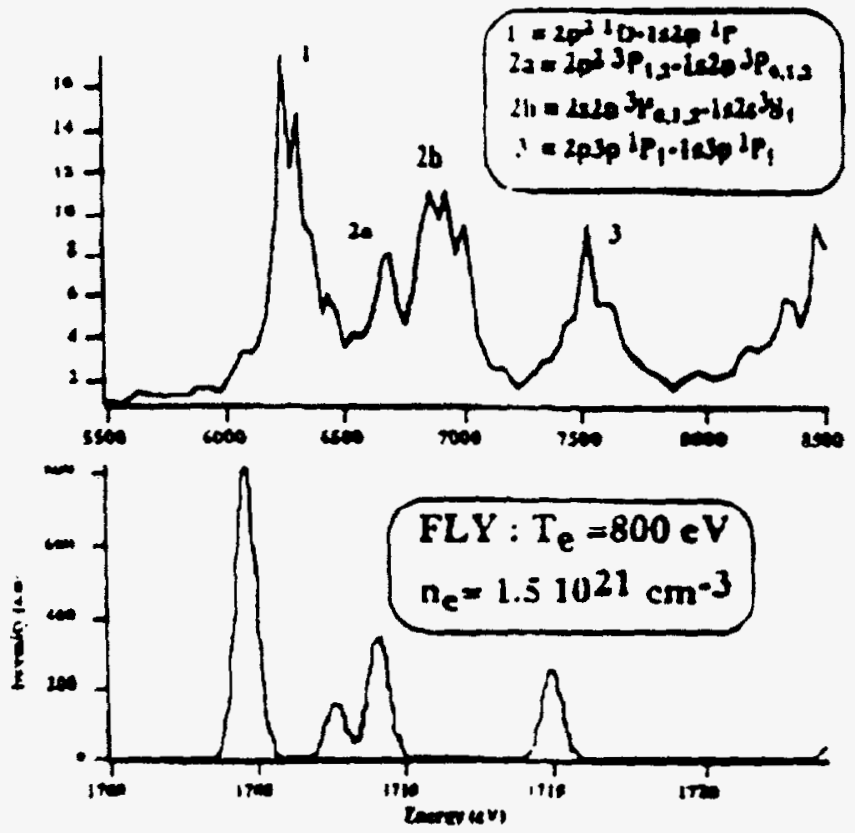

Figure 3: Compen ison of die colculaed and measured II-like Lyman a dietectronic salellite spectrum.

\subsection{Dimensions of the collision region}

We have measured the size of the collision zone along and acrnss the inter-iarget axis by different diagnostics: monochromatic images, pinhole images. and the OHM nat ciyntal spectuugtaph. All the niagnnstic: measured X-ray emiscion at different wavelengllis und used different detectors. Pinhole images filceied will alumiced mylar give a lateral expansiun much larger than monochromatic images at $6.635 \mathrm{~A}$ and crystal spectrographs in the keV range, uxsnciated with He-like cmission. At 600 and $900 \mu \mathrm{m}$ inter-target dixtance the $X$-my emssion of He-likr ions gave $300 \mu \mathrm{m}$ laterai expansion and the pinhole camera gave $800 \mu$ In FWHM profiles at $900 \mu$ ultiteriarxel distance as shown in Pigure 4a. This difference has been explained by measuring the lateral spread of He. Be and B like emisstion with the OHM crystal spectrograph as shown in Figure 40 . He-inke and Be-like emissions respectively at $46.056 \lambda$ and $46.391 A$ cxtend on protili of $200-250 \mu \mathrm{m} \Gamma W 1$ IM. as $B$-like ions 
spread on $970 \mu \mathrm{mi}$ fol a sliul done at $900 \mu \mathrm{m}$ infenarget disiance. This can he attributed to a temprerature profile rather steep for the highest temperalurc region and a temperature niatesu at low leulueratures. This measurement supports the hypothests of homogeneity of the He-like emisston region assumed for the Doppler uruadening deconvolutinn. Further numerieal analysis will quantify this effert.
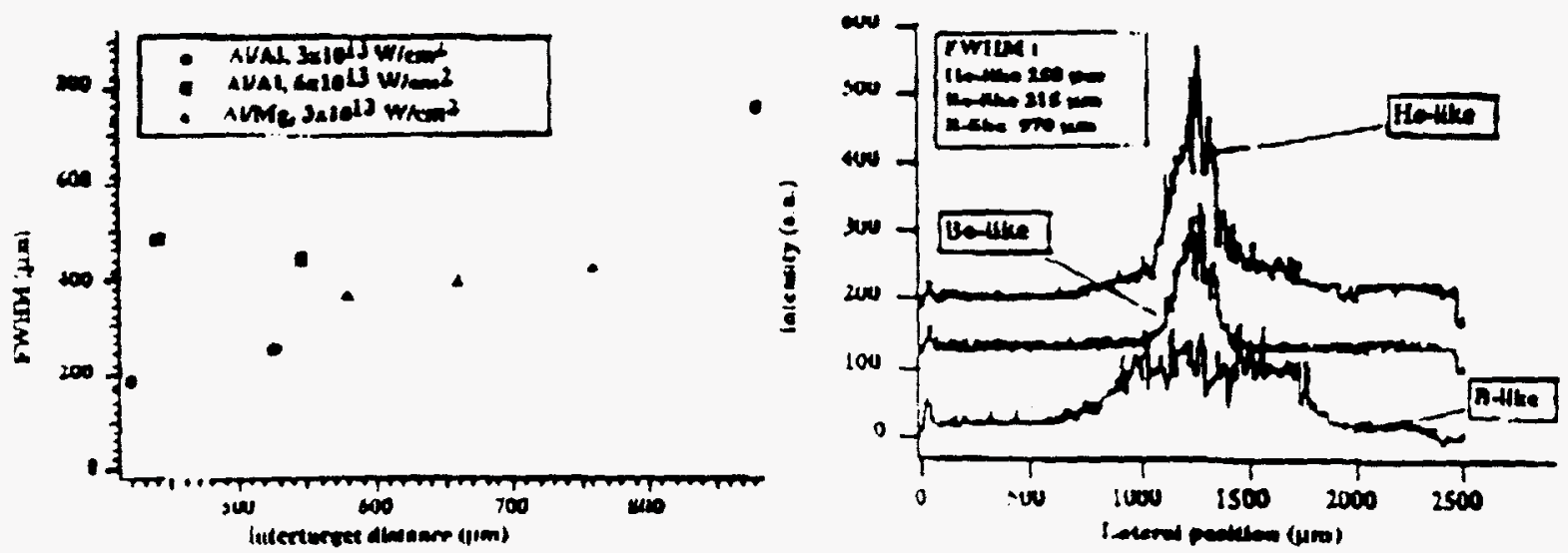

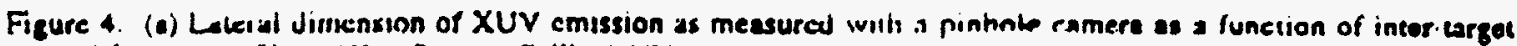

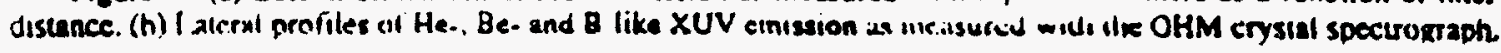

\section{NUMERICALSIMULATIONSAND INTEGSPRETATION OE THE RESULTS}

Numerical simulations have been performed with the multifluid code MULTIF in understand better the interpenetration and the exchange of ion kinetic cnergy to thermal energy. MULTIF is a multispecies. Eulerian, 1.5-D nuid code in which the Iateral expansion is taken into account through a self-similar model. 13 The cude uses the improved nux-enirerten imanspor modules of Boris, 14 and tlux-limited Spitzer conductivity. The carly laser ahsorptivil ulld fuil acceleration stages are modelled hy the 1.5.D fuid code FILM. $15 \wedge$ simple cstimatc of ridiative cooliux and iunization is made with a inulispecies LIE calculation of innization states. The output of this code was post procassed by ILY and by line delatted spectroscopy model TKAN.SPF. 10 in enmpore the calculuted $X$-ray emission of the plasma directly with the experimental results. Extcillcnt agreement between the interpenetratinn distance detcrmined fron the culculaced $A l$ HeB axial cimsston prntile and experiment has beea obtained. 17 The maximum values of the plasma paramesen $T_{\text {e.max }}$ and $T_{i \text {,max }}$ at target midplane as calculated with MULTIP are shown in loble $I$ and their tinc variation is show"l in Figure 5 for an irradiance $n t h \times 1013 \mathrm{~W} / \mathrm{cm}^{2}$ and for the experimental inter-larget distances. Clectron deusity is of order $10^{21} \mathrm{~cm}^{.3}$. and inn temperature rises $1020.27 \mathrm{kcV}$ (see Figure 5). The electron density measured with the dielectuutic satellites is in good agrecment wirh ine valie shown in Figure $S_{2}$.

the most striking feature happening when the distance is incicased cu $900 \mu \mathrm{m}$. is that the maximum of $T_{i}$ occurs much later at targe! midplane than the maxima of $n_{e}$ and $T_{e}$. This is linked to the interpentration of the plasmas. Thic cullision region spreids in space and lime ann the maximum ion iemperanure occurs lates, when the relative velocity of the coutersireaming plasillas cuanceis. Figure 5 asso shows the ume variation of the inaximum of the Heß litie pruile calculared with MULTIF+FLY. The predicted Heß line eirussion does not follow the variatiun ot the elerimn density and temperature closely due to non stationnarity. It lasis for only $100 \mathrm{lu} 2(x)$ ) 1 . in agreement whth the time-resolved monochromatic imaging meusurements. Due to this short duration. the Ijeß emissinn sampies the ion remperarure over a comparable time scale. at a lime clusc (b) the maxisuuili uf elcciron density and tesspetruture. 

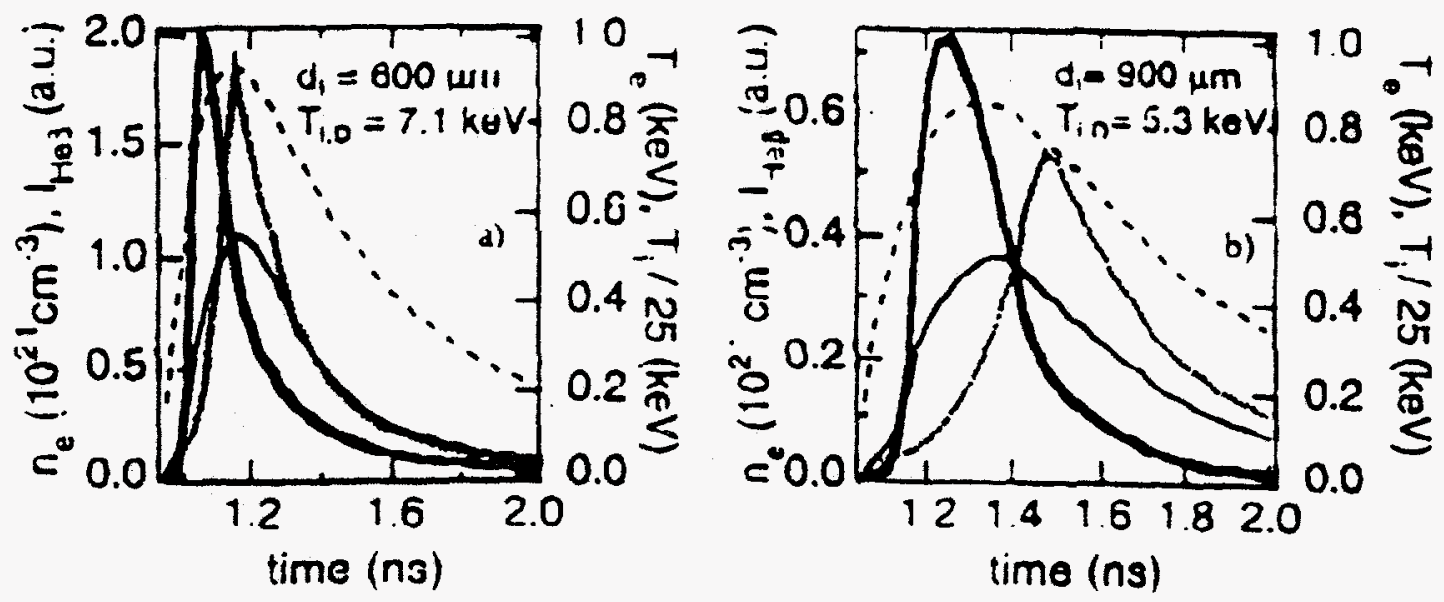

Figure 5: Tempural eveluaun of ine plasme paronketers as calculated liy MULTIP and of ine maximum of the Heb line

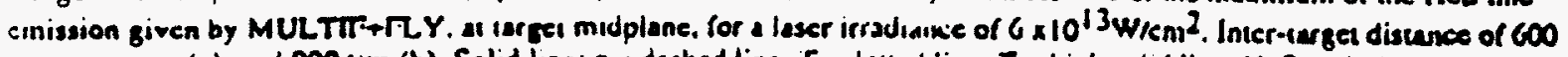

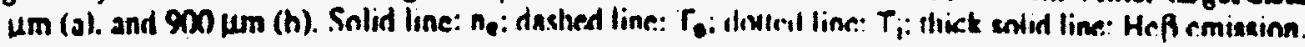

Secondly. Doppler brosdening measurements give an ion temperature very different from the theoretically expected maximum of $T_{1}$. This effect is particularty important in the long inter-taget separainn regume, when the maximum of $T_{i}$ occurs long atter the peak of elestron density and temperature. The spectral width of the cime-integrated Hefs line profile at the center of the inter-target

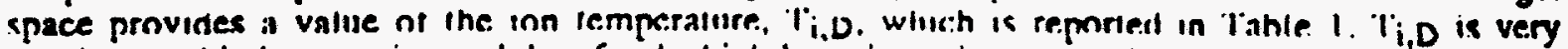

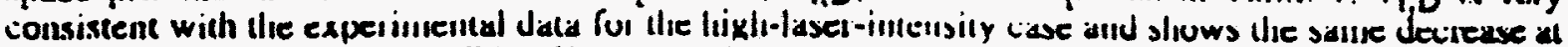
high inter-target separation. This effect is partucularly impertant in the wide soparation rogimo when the maximum of $T_{i}$ occurs long after the peak of electron ciensity and temperature. This decrease is an experimental evidenee that the plasinas interpenetrate.

\section{S. CONCLIISION}

$X$-ray diagnostics associated with multifluld simulations have kiven a koud understandituk of the collision of couter. screaming plessmos. The de velopment of new spectrosenpic and imaging tools of very high temporal. spatial and speciral resnluminn adapton have permitted the measurement of the paraneters of the collision. It is demunstated that the tor otdally bent crystols can be efficiently used for plasma opectroseopy and imuging. The comparikon of llic cxpersmental data to numerical simulations have evidenced that at high laser imadiances and large inter-turset distances. 1.e. when density decreases and relative velocity of the counter-streaning plasmns increases, interpenetration occurs in a large region and ion heating oceurs later when relauve velocitues cancel.

\section{ACKNOWLEDSIMFNTS}

This work has been parily finariced by Ike LEC llwuupli lie Human Capital and Mobility large facilities and networks programs. We want to thank the l.lli.I sitaif, the "Laboratoire des cibles" de l' Instinut de Physique Nucleatre and the Ceitre de Uensitumeiric de linstinut d'Optique in Puris -Sud University. 


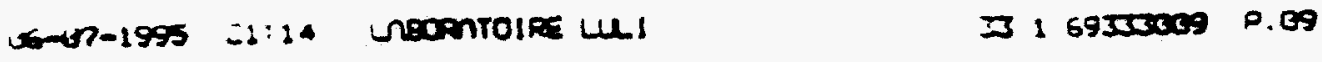

1. R.A. Bosch et.al.. Phyr. Hluids B 4, 979 (1992).

2. R.L. Berger et.al., Phys. Fuids B 3. 3 (1991).

3. P.W. Kambo and J. Denavit, Phys. Plasmas 1, 4USO, (1994).

4. C.A. Buck. R.L. Kautrman. H.M. Hell. and J.D. Kilkenny, Rev. Sci. Insir. 66. 7 G4 (1995).

S. D. Jurazcek, private commiunicutiun.

0. A. Decoster, M. Demoutins and G. Schurz, private communiczicun.

7. O. Larrocile, Phys. Fluids B 5. $281 \mathrm{~h}(14) 3)$.

8. R.J. Taylor, A.J. Mackillon, R. Mansukhani. and O. Willi. IJKAL Annual Report (1994. unpublishert). p.69.

9. M. Dirkemuller et.al.. "Opt. Comm. (in prese, l(995).

10. O. Renner et.2l., Laser and Part. Deams 12, 539 (199d)

11. Bamsley er al. Rev. Tict. Instrum. 61 (10) 2159 (1900)

12. R.W. Lec, B.L. Whitten und R.E. Strout. J. Quant. Sincet. Kadiat. Transf. 32.91 (1981).

13. J. Virmont, N. Grandjouan and A. Klisnick. LULI repest 1990.

14. D. L. Book. J. P. Bons. S. Y. /alesak. "Finite-Difference Techniqucs for Vectorized Fluid Dynamics Culeulauons", ediced Uy D. L. Book. (Snrınger Verlag. New York, 1981), p. 29.

15. J.C.. S iauthier et.2l. J. Phys. D 16, 321 (1983) and refericnces dierein.

16. O. Pevrusse. Phys. Fluids B 4. 2(1x)II (1992).

17. C. Chenais-Popovics. O. Rallu. P. Renaudin. J.C. Gaullier. F. Gillemn. O. Lindenmeyer, H. Kawagnshi*. M. Dirksmoller, 1. Uschmonn, T. Missalls, P. Soudliauss. E. Forster. O. Renner. E. Krousky. H. Pepin. O. Larroche. U. Yeynisse. T.D. She pard. submirted to Phys. Rev. Letters

"This work was performed under the auspices of the U.S. Department of Energy by Lawrence Livermore National Laboratory under contract No. W-7405-Eng-48. 